\title{
Investigation of benthic marine litter in the Yumurtalık Fishing Port
}

\author{
Özgür Yılmaz ${ }^{1, a, *}$, Celal Erbaş ${ }^{1, b}$, Mahmut Ali Gökçè \\ ${ }^{1}$ Underwater Technology Programme, Yumurtallk Vocational School, Çukurova University 01680 Yumurtalı, Adana, Turkey \\ ${ }^{2}$ Department of Aquaculture, Faculty of Fisheries, Çukurova University, 01330 Adana, Turkey
}

*Corresponding author

\begin{tabular}{l|l}
\hline A R T I C L E I N F O & A B S T R A C T \\
\hline Research Article & $\begin{array}{l}\text { Marine litter, which can be seen in almost all seas in recent years, is a serious problem for the } \\
\text { environment. Similarly, the same problem also exists in Turkey's seas. This study was carried out in } \\
4 \text { different areas, each of which is } 100 \mathrm{~m}^{2}, \text { in the Yumurtalik Fishing Port in İskenderun Bay. Marine } \\
\text { litter was removed from the seabed by diving in these selected areas in April } 2016 \text { and June } 2017 . \text { In } \\
\text { the study, a total of } 157.2 \mathrm{~kg} \text { of rubber }(49.5 \%), 118.9 \mathrm{~kg} \text { of glass }(37.4 \%), 21.61 \mathrm{~kg} \text { of plastic }(6.8 \%) \\
\text { and } 19.94 \mathrm{~kg} \text { of metal }(6.3 \%) \text { marine litter were detected and removed. It was determined that the } \\
\text { Accepted : } 16 / 01 / 2021 \\
\text { litter from underwater reduces their amount, it appears to occur again the next year. Our result shows } \\
\text { that different solutions should be produced to reduce marine litter. }\end{array}$
\end{tabular}

Keywords:

Marine litter

Sea pollution

Environment

Diving

İskenderun Bay

Türk Tarım - Gıda Bilim ve Teknoloji Dergisi, 9(2): 272-276, 2021

\section{Yumurtalık Balıkçı Barınağı'nda Bentik Deniz Çöpü Araştırması}

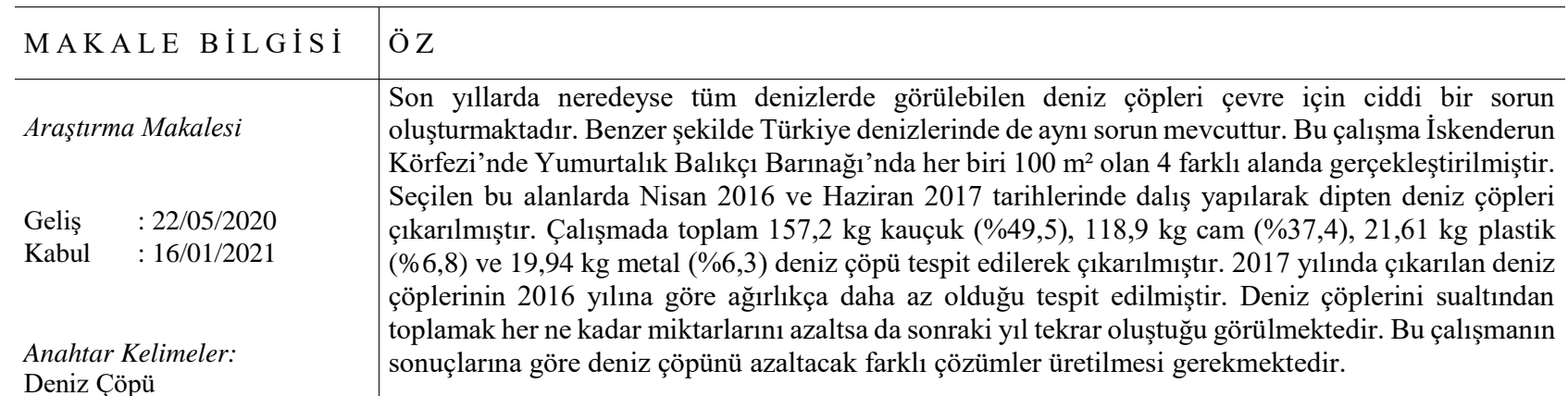

Deniz Kirliliği

Çevre

Dalıș

İskenderun Körfezi 


\section{Introduction}

Marine litter, is one of the most serious, rapidly developing and worsening global environmental problems. It consists of an extremely wide variety of materials and sizes and originates from many unspecified sources. Approximately half of the global waste production, which is expected to be 8 billion tons in 2025, are non-biodegradable materials such as plastic and metal (Galgani et al., 2015). Therefore, it has become one of the important problems that have been focused on in recent years (Borja and Elliott, 2019). According to the Cheshire et al. (2009), marine litter is "waste, discarded or lost material resulting from human activities - marine litter is any such material that has made it into the marine environment, including material found on beaches or material that is floating or has sunk at sea". Today, marine litter can be seen in the whole sea, with its ecological, economic and social effects (Cheshire et al., 2009; Thompson et al., 2009).

The abundance and spatial distribution of marine debris varies from hydrodynamics, geomorphology and human factors (Galgani et al., 2000). There are many different types of marine litter such as plastic, glass, metal and textiles on the sea surface or seafloor (Olguner et al., 2018). Marine litter is abundantly detected in the Mediterranean because of a dense coastal population, ship traffic and current (Barnes et al., 2009).

Many studies have been carried out by collecting marine litter in the Turkish coast of the Mediterranean. These studies concentrated on marine debris and litters prediction by artificial intelligence (Balas et al., 2004), distribution and composition (Olguner et al., 2018), identifying abundance and source (Aydın et al., 2016), microplastics (Gündoğdu, 2017; Gündoğdu et al., 2018) and mesoplastics (Gündoğdu and Çevik, 2017), microplastics-fish relationship (Güven et al., 2017), and fouling assemblage of benthic plastic debris as well (Gündoğdu et al., 2017).

The present study was carried out in the town of Yumurtalik, which has a high agricultural, tourism and fisheries potential. Yumurtalik is in the province of Adana and located on the Eastern Mediterranean coast of Turkey. Amateur anglers and tourists are mostly concentrated in the coastal area during the summer period and the Yumurtalik Fishing Port is one of the popular places frequented by the visitors. Although, mostly small-scale fishers use this port all year around, trawlers from Karataş and İskenderun districts also use the fishing port during the fishing season. While fishermen do the maintenance and repair of their boats and fishing gear on this dock, various restaurants and fishermen in the port serve the local people and visitors. For this reason, an increase in pollution is observed in this area, especially at the end of each summer season.

This study aims to identify and reveal the marine litter in the seabed of Yumurtalik Fishing Port, which is an area of ecologically important. Thus, by looking at the current situation, determining the factors that cause marine litter, and providing the data that can form a basis for the studies to take the necessary precautions and to be carried out to minimize the pollution were aimed.

\section{Material and Method}

Sampling was performed in April 2016 and June 2017 in the Yumurtalik Fishing Port of Adana at four selected areas (Lat: 36,767778 - Long: 35,791667; Lat: 36,767778 - Long:
35,794722; Lat: 36,766111- Long: 35,794444; Lat: 36,766111- Long: 35,791944) (Figure 1).

Of all the areas around the entrance of the fishing port and inside, each of them covers about $100 \mathrm{~m}^{2}$ and is between 0.5 and 2.5 meters in depth. The study area was divided into four regions according to usage density. The first (area 1) region was determined as the most used area and the other areas were numbered up to 4 according to their usage intensity.

A total of 16 divers took part in the study, and the study was completed in three weeks. Following the diving tables in the US Navy Diving Manual (Manual, 2011); the divers, in groups of two and at intervals of 60 minutes, dived with self-contained and surface-supplied diving systems. Marine litters found on the seabed were extracted with the dives. Litters were weighted and classified according to the Guidance on Monitoring of Marine Litter in European Seas of the EU Marine Strategy Framework Directive (MSFD) (Directive, 2013).

In the statistical tests, the weight values of the extracted materials in 2016 and 2017 were analyzed by using ShapiroWilk's test and it was concluded that the values did not fit a normal distribution $(\mathrm{P}<0.05)$ (Shapiro \& Wilk, 1965). In the analysis, normal distribution of the data was examined and a difference between the averages was found by using the Wilcoxon Test $(\mathrm{P}<0.05)$. All analysis was performed using the SPSS v20 package software at the 0.05 level of significance.

\section{Results}

The values according to their material type of the marine litter extracted from the areas $(\mathrm{kg})$ in this study can be seen in table 1.

A considerable difference in the total values of the weight of extracted wastes between 2016 and 2017 was observed $(\mathrm{P}<0.05)$. The change in the four areas between 2016 and 2017 was also tested. A considerable difference between the years was found in area 1 . The remaining three areas did not show a statistically significant change $(\mathrm{P}>0.05)$.

\section{Discussion and Conclusions}

Between 2013-2015, Yumurtalık Vocational School and Yumurtalık Municipality performed marine litter cleaning between Yumurtalik Fishing Port and the beach nearby (Anonymous, 2018). However, no records were kept about the marine litter generated. Although the working area was cleaned in 2013, 2014, and 2015, marine litters were found and extracted on seabed in 2016.

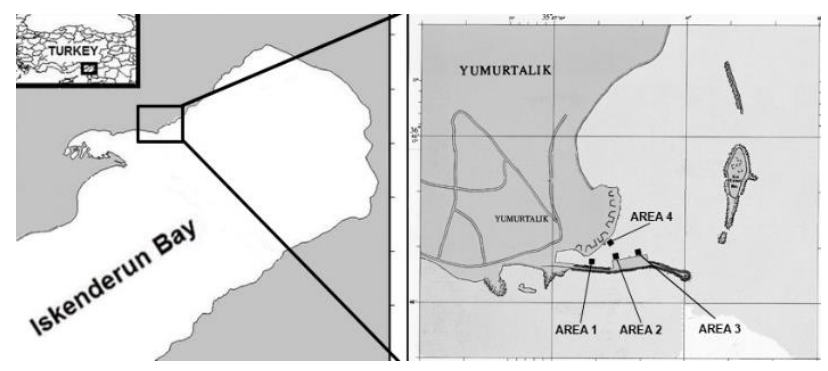

Figure 1. Study area 


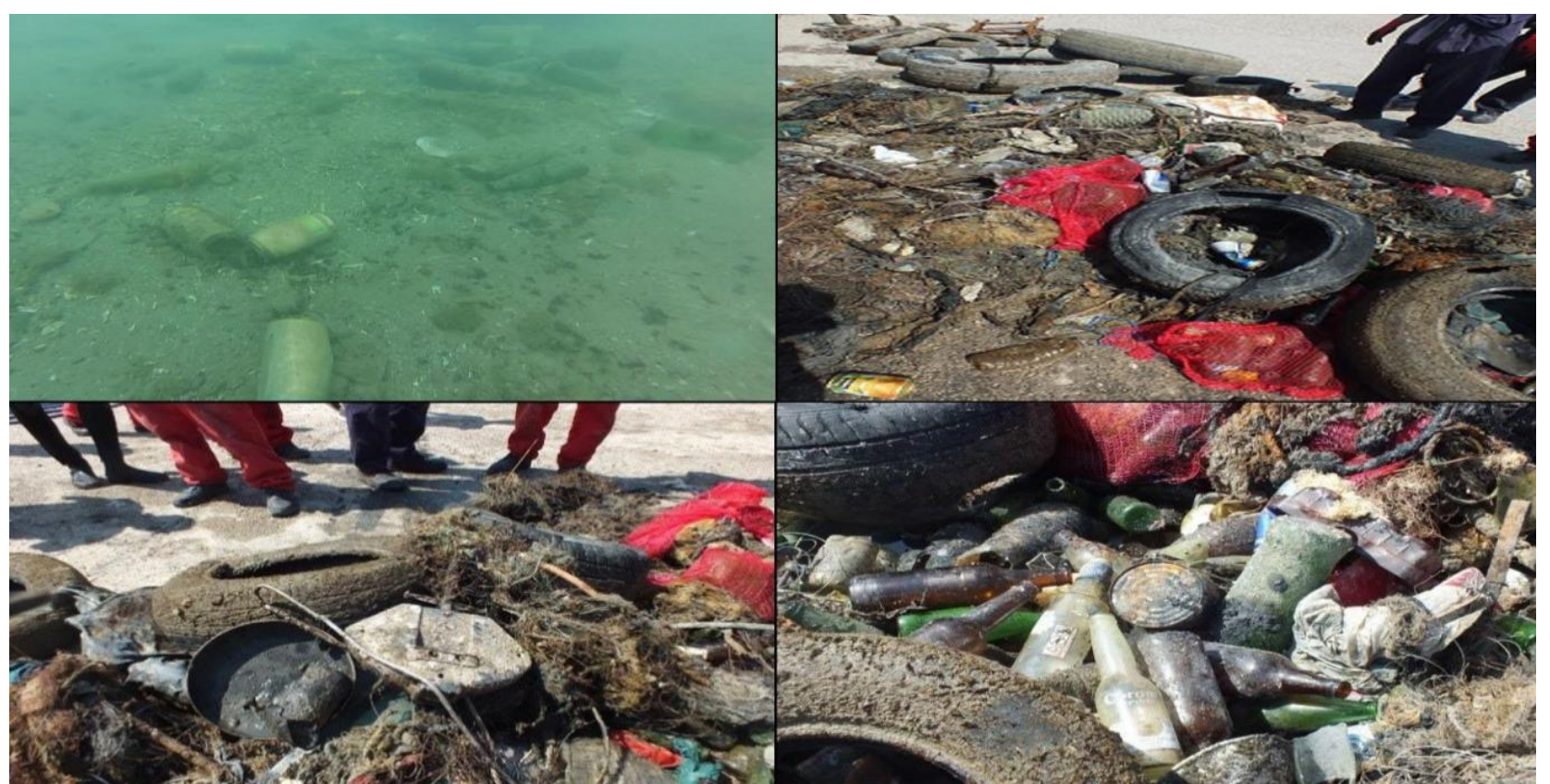

Figure 2. The Marine litters that are extracted from the designated areas.

Table 1. Total weights $(\mathrm{kg})$ of the collected marine litter in 2016-2017

\begin{tabular}{|c|c|c|c|c|c|c|c|c|}
\hline \multirow{2}{*}{ Marine litter type } & \multicolumn{2}{|c|}{ Area 1} & \multicolumn{2}{|c|}{ Area 2} & \multicolumn{2}{|c|}{ Area 3} & \multicolumn{2}{|c|}{ Area 4} \\
\hline & 2016 & 2017 & 2016 & 2017 & 2016 & 2017 & 2016 & 2017 \\
\hline A. Plastics & 6.24 & 3.22 & 1.46 & 1.73 & 4.55 & 3.77 & 0.42 & 0.22 \\
\hline A1. Bags & 0.00 & 0.00 & 0.00 & 0.00 & 0.00 & 0.00 & 0.00 & 0.00 \\
\hline A2. Bottles & 0.64 & 0.32 & 0.76 & 0.43 & 0.85 & 0.82 & 0.22 & 0.22 \\
\hline A3. Food wrappers & 0.00 & 0.00 & 0.00 & 0.00 & 0.00 & 0.00 & 0.00 & 0.00 \\
\hline A4. Sheets & 0.00 & 0.00 & 0.00 & 0.00 & 0.00 & 0.00 & 0.00 & 0.00 \\
\hline A5. Other plastic objects & 2.20 & 0.00 & 0.00 & 0.00 & 0.00 & 0.45 & 0.00 & 0.00 \\
\hline A6. Fishing nets & 0.00 & 0.00 & 0.00 & 0.00 & 0.00 & 0.00 & 0.00 & 0.00 \\
\hline A7. Fishing lines & 0.00 & 0.00 & 0.00 & 0.00 & 0.00 & 0.00 & 0.00 & 0.00 \\
\hline A8. Other fishing related & 0.00 & 0.00 & 0.00 & 0.00 & 0.00 & 0.00 & 0.00 & 0.00 \\
\hline A9. Ropes/strapping bands & 3.40 & 2.9 & 0.70 & 1.30 & 3.70 & 2.50 & 0.20 & 0.00 \\
\hline A10. Sanitaries(diapers,etc.) & 0.00 & 0.00 & 0.00 & 0.00 & 0.00 & 0.00 & 0.00 & 0.00 \\
\hline B. Rubber & 12.70 & 9.60 & 36.30 & 23.20 & 47.30 & 28.10 & 0.00 & 0.00 \\
\hline B1. Tyres & 12.70 & 9.60 & 36.30 & 23.2 & 47.30 & 28.1 & 0.00 & 0.00 \\
\hline B2. Other(gloves,shoes,etc.) & 0.00 & 0.00 & 0.00 & 0.00 & 0.00 & 0.00 & 0.00 & 0.00 \\
\hline C. Metals & 0.96 & 0.68 & 7.13 & 3.19 & 3.64 & 3.28 & 0.53 & 0.53 \\
\hline $\mathrm{C} 1$. Beverage cans & 0.26 & 0.18 & 0.31 & 0.29 & 0.54 & 0.48 & 0.13 & 0.18 \\
\hline C2. Other food cans/wrappers & 0.00 & 0.00 & 0.00 & 0.00 & 0.00 & 0.00 & 0.00 & 0.00 \\
\hline C3. Middle size containers & 0.00 & 0.00 & 0.00 & 0.00 & 0.00 & 0.00 & 0.00 & 0.00 \\
\hline C4. Large metalic objects & 0.00 & 0.00 & 5.52 & 1.70 & 0.00 & 0.00 & 0.00 & 0.00 \\
\hline C5. Cables & 0.00 & 0.00 & 0.00 & 0.00 & 0.00 & 0.00 & 0.00 & 0.00 \\
\hline C6. Fishing related & 0.70 & 0.5 & 1.30 & 1.2 & 3.10 & 2.8 & 0.40 & 0.35 \\
\hline D. Glass/ceramics & 12.40 & 9.70 & 15.30 & 11.60 & 23.70 & 17.20 & 16.40 & 12.60 \\
\hline D1. Bottles & 12.40 & 9.70 & 15.30 & 11.60 & 23.70 & 17.20 & 16.40 & 12.60 \\
\hline D2. Pieces of glass & 0.00 & 0.00 & 0.00 & 0.00 & 0.00 & 0.00 & 0.00 & 0.00 \\
\hline D3. Ceramic jars & 0.00 & 0.00 & 0.00 & 0.00 & 0.00 & 0.00 & 0.00 & 0.00 \\
\hline D4. Large objects(specify) & 0.00 & 0.00 & 0.00 & 0.00 & 0.00 & 0.00 & 0.00 & 0.00 \\
\hline E. Textiles / natural fibers & 0.00 & 0.00 & 0.00 & 0.00 & 0.00 & 0.00 & 0.00 & 0.00 \\
\hline E1. Clothing (clothes,shoes) & 0.00 & 0.00 & 0.00 & 0.00 & 0.00 & 0.00 & 0.00 & 0.00 \\
\hline E2. Large pieces (carpet, etc.) & 0.00 & 0.00 & 0.00 & 0.00 & 0.00 & 0.00 & 0.00 & 0.00 \\
\hline E3. Natural ropes & 0.00 & 0.00 & 0.00 & 0.00 & 0.00 & 0.00 & 0.00 & 0.00 \\
\hline F. Wood (processed) & 0.00 & 0.00 & 0.00 & 0.00 & 0.00 & 0.00 & 0.00 & 0.00 \\
\hline G. Paper / cardboard & 0.00 & 0.00 & 0.00 & 0.00 & 0.00 & 0.00 & 0.00 & 0.00 \\
\hline H. Other (specifiy) & 0.00 & 0.00 & 0.00 & 0.00 & 0.00 & 0.00 & 0.00 & 0.00 \\
\hline I. Unspecified & 0.00 & 0.00 & 0.00 & 0.00 & 0.00 & 0.00 & 0.00 & 0.00 \\
\hline Total & 32.30 & 23.20 & 60.19 & 39.72 & 79.19 & 52.35 & 17.35 & 13.35 \\
\hline
\end{tabular}


Table 2. Percentage of marine litter types by weight

\begin{tabular}{l|ccc}
\hline \multicolumn{1}{c|}{ Marine litter type } & 2016 & 2017 & Total \\
\hline A. Plastics & 6.7 & 7.0 & 6.8 \\
B. Rubber & 50.9 & 47.3 & 49.5 \\
C. Metals & 6.5 & 6.0 & 6.3 \\
D. Glass/ceramics & 35.9 & 39.7 & 37.4 \\
E. Textiles / natural fibers & 0 & 0 & 0 \\
F. Wood (processed) & 0 & 0 & 0 \\
G. Paper / cardboard & 0 & 0 & 0 \\
H. Other (specifiy) & 0 & 0 & 0 \\
I. Unspecified & 0 & 0 & 0 \\
\hline
\end{tabular}

In the light of the obtained data, it has been understood that the pollution formed in time cannot be prevented completely. Although the litter accumulation detected during the 2017 study is relatively less than the previous year $(\mathrm{P}<0.05)$, studies carried out in both 2016 and 2017 revealed that such amount of litter accumulation can occur in a year period of time.

When the study fields were considered separately, the annual change of litter accumulation in area 1 was statistically significant, while the difference in the other three areas by years was not significant $(\mathrm{P}>0.05)$. In the study, it was observed that the amount of marine litter extracted from area $1-4$ was less than that of areas $2-3$. It is estimated that this may be due to the fact that the areas 1 and 4 are shallower than the others and the underwater is easily visible, and thus people probably avoid littering in these areas.

Marine litter constitutes a threat to the coastal and marine ecosystems, and has negative effects primarily on aquatic organisms and consequently on human health. In addition, marine litter accumulation is an undesirable situation in coastal settlements and touristic areas due to causing bad appearance and odour (Guneroglu, 2010). In recent years, various studies have been carried out on the pollution and marine litter accumulation on the coasts, sea floor and sea surface in the Black Sea and the Mediterranean, and many observational data have been obtained. While marine litter was mainly classified as artificial polymer materials, plastics, rubber, textiles, metal, paper/cardboard/cardboard, glass/ceramic, fishing materials, wood, natural products, hybrid and miscellaneous (Miladinova et al., 2020; Moncheva et al., 2016; Simeonova et al., 2020; Stanev and Ricker, 2019; UNEP/MAP, 2015), plastic constituted the majority of marine litter in most of these studies.

According to the report of UNEP/MAP (2015), the most of the marine litter in the Mediterranean comes from land-based sources and marine litter found on beaches originates from tourism and recreational activities and is composed mainly of plastics (bottles, bags, caps/lids, etc.), aluminium (cans, pull tabs) and glass (bottles). In another study carried out on marine litter obtained from the sea bed in the Black Sea, while rubber was the least abundant item group, plastic was the most abundant debris with a rate of 68\% (Moncheva et al., 2016). Paiu et al. (2017) classified the marine litter data they obtained on the Romanian Black Sea coast. In their survey, although rubber was encountered at a very low rate $(3.76 \%)$, they found that the amount of plastic $(80.60 \%)$ was significant among the litter classified.

The results of this study reveal that the different types of marine litter can be found on the seabed of Yumurtalik Fishing Port. In the present study, the most abundant groups of marine litter found in the study area were rubber (49.5\%) and glass/ceramics (37.4\%) (Table 2). In the study conducted by Olguner et al. (2018) in Antalya, rubber, parallel to our findings, was the most detected marine litter with a rate of $40.7 \%$ by weight. Car tires constituted all of the marine litter described as rubber in this study. There is a variety of different sized fishing boats in the study area. Boats with relatively more draft use the deep regions of the shelter as docking and mooring. Therefore, it was found remarkable that the vehicle tire was more than other areas in the materials submerged in area 2 and area 3. It is known that usually 3-4 car tires are boarded on top of each other as fenders by larger boats. As a result of friction in the shelter caused by seasonal effects, the tires fall into the water over time. Since falling tires cannot be noticed due to the invisible depth, this makes both the detection of the contaminant and the cleaning from the surface difficult.

Although very low amounts of glass/ceramic (10\% and less) were found in marine litter in some of the studies (Guneroglu, 2010; Simeonova et al., 2020; UNEP/MAP, 2015), the second most common group among marine litter determined in the Yumurtalık Fishing Port study was glass/ceramic. Yumurtalık Fishing Port does not have a river connection and it is also a closed area to currents and strong winds. Therefore, the transportation of marine litter from remote areas to here does not seem possible. As stated in the report of UNEP (2005), people throwing marine litters directly and deliberately into the sea is one of the main reasons of marine litter pollution. Therefore, it can be speculated that the glass/ceramics and plastic marine litter accumulation in this port is caused by the local people and tourist activities.

When the marine litters produced in all four areas are examined according to their types, it is seen that the areas contain materials with different density from each other. It can be speculated that this is related to the intended use of the areas and the frequency of use. As a consequence, implementing routine underwater cleaning and fisherman training programs, and placing a large number of noticeable warning signs and making an arrangement of recycling litter storage areas for residents, fisherman and tourists using the area, can be considered to be effective in decreasing the pollution of the fishing port.

\section{References}

Anonymous 2018. Yumurtalı underwater cleaning and awareness. Retrieved from https://www.milliyet.com.tr/ yerel-haberler/adana/denizden-cikan-atiklardan-sanat-eseriyaptilar-10183345 
Aydın C, Güven O, Salihoğlu B, Kıdeyş AE. 2016. The influence of land use on coastal litter: an approach to identify abundance and sources in the coastal area of Cilician Basin, Turkey. Turkish Journal of Fisheries and Aquatic Sciences, 16(1): 029-039.

Balas CE, Ergın A, Williams AT, Koc L. 2004. Marine litter prediction by artificial intelligence. Marine Pollution Bulletin, 48(5-6): 449-457.

Barnes DK, Galgani F, Thompson RC, Barlaz M. 2009. Accumulation and fragmentation of plastic debris in global environments. Philosophical Transactions of the Royal Society B: Biological Sciences, 364(1526): 1985-1998.

Borja A, Elliott M. 2019. So, when will we have enough papers on microplastics and ocean litter? Marine Pollution Bulletin, 146: 312-316.

Cheshire A, Adler E, Barbière J, Cohen Y, Evans S, Jarayabhand S, Jeftic L, Westphalen G. 2009. UNEP/IOC Guidelines on Survey and Monitoring of Marine Litter Regional Seas Reports and Studies No. 186 IOC Technical Series No. 83 Nairobi: UNEP

Directive SF. 2013. Guidance on monitoring of marine litter in European Seas.

Galgani F, Leaute J, Moguedet P, Souplet A, Verin Y, Carpentier A, Goraguer H, Latrouite D, Andral B, Cadiou Y. 2000. Litter on the sea floor along European coasts. Marine Pollution Bulletin, 40(6): 516-527.

Galgani F, Leaute J, Moguedet P, Souplet A, Verin Y, Carpentier, A, Cadiou Y. 2000. Litter on the sea floor along European coasts. Marine Pollution Bulletin, 40(6): 516-527.

Gündoğdu S. 2017. High level of micro-plastic pollution in the Iskenderun Bay NE Levantine coast of Turkey. Su Ürünleri Dergisi, 34(4): 401-408.

Gündoğdu S, Çevik C. (2017). Micro-and mesoplastics in Northeast Levantine coast of Turkey: The preliminary results from surface samples. Marine Pollution Bulletin, 118(1-2): 341-347.

Gündoğdu S, Çevik C, Ayat B, Aydoğan B, Karaca S. 2018. How microplastics quantities increase with flood events? An example from Mersin Bay NE Levantine coast of Turkey. Environmental pollution, 239: 342-350.

Gündoğdu S, Çevik C, Karaca S. 2017. Fouling assemblage of benthic plastic debris collected from Mersin Bay, NE Levantine coast of Turkey. Marine Pollution Bulletin, 124(1): 147-154.
Guneroglu A. 2010. Marine litter transportation and composition in the Coastal Southern Black Sea Region. Scientific Research and Essays, 5(3): 296-303.

Güven O, Gökdağ K, Jovanović B, Kıdeyş AE. 2017. Microplastic litter composition of the Turkish territorial waters of the Mediterranean Sea, and its occurrence in the gastrointestinal tract of fish. Environmental pollution, 223: 286-294.

Manual UND. 2011. Revision. 6, Change A. Published by the Direction of Commander, Naval Sea System Command. Washington, DC: Department of Defense.

Miladinova S, Macias D, Stips A, Garcia-Gorriz, E. 2020. Identifying distribution and accumulation patterns of floating marine debris in the Black Sea. Marine Pollution Bulletin, 153: 110964.

Moncheva S, Stefanova K, Krastev A, Apostolov A, Bat L, Sezgin M, Sahin F, Timofte F. 2016. Marine litter quantification in the black sea: a pilot assessment. Turkish Journal of Fisheries and Aquatic Sciences, 16(1): 213-218.

Olguner MT, Olguner C, Mutlu E, Deval MC. 2018. Distribution and composition of benthic marine litter on the shelf of Antalya in the eastern Mediterranean. Marine Pollution Bulletin, 136: 171-176.

Paiu A, Mirea-Cândea M, Paiu RM, Gheorghe AM. 2017. Composition and spatial distribution of marine litter along the Romanian Black Sea Coast. Revista Cercetări Marine-Revue Recherches Marines-Marine Research Journal, 47(1): 232239.

Shapiro SS, Wilk MB. 1965. An analysis of variance test for normality (complete samples). Biometrika, 52(3/4): 591-611.

Simeonova A, Chuturkova R, Toneva D, Tsvetkov M. 2020. Plastic pollution along the Bulgarian Black Sea coast: Current status and trends. In (pp: 361).

Stanev EV, Ricker M. 2019. The Fate of Marine Litter in Semienclosed Seas. Case of the Black Sea. Frontiers in Marine Science, 6: 660.

Thompson RC, Moore CJ, Vom Saal FS, Swan SH. 2009. Plastics, the environment and human health: current consensus and future trends. Philosophical Transactions of the Royal Society B: Biological Sciences, 364(1526): 21532166.

UNEP, 2005. Marine Litter: An Analytical Overview. Nairobi, Kenya: United Nations Environment Programme.

UNEP/MAP, 2015. Marine Litter Assessment in the Mediterranean. In: UNEP/MAP Athens. 